\title{
Induced Mitogenic Activity in AML-12 Mouse Hepatocytes Exposed to Low-dose Ultra-Wideband Electromagnetic Radiation
}

\author{
W. C. Dorsey ${ }^{1}$, B. D. Ford ${ }^{2}$, L. Roane ${ }^{1}$, D. T. Haynie ${ }^{3}$, and P. B. Tchounwou ${ }^{4 *}$ \\ ${ }^{1}$ Wildlife Biology Unit, Grambling State University, Grambling, LA. USA. \\ ${ }^{2}$ Department of Anatomy and Neurobiology, Morehouse School of Medicine, Atlanta, GA. USA. \\ ${ }^{3}$ Biomedical Engineering \& Physics, Institute for Micromanufacturing, Louisiana Tech University, Ruston, LA. USA. \\ ${ }^{4}$ Molecular Toxicology Research Laboratory, NIH-Center for Environmental Health, College of Science, Engineering, and \\ Technology, Jackson State University, Jackson, MS, USA. \\ *Correspondence to Dr. Paul B. Tchounwou. Email: paul.b.tchounwou@jsums.edu
}

Received: 15 November 2004 / Accepted: 06 February 2005 / Published: 30 April 2005

\begin{abstract}
Ultra-wideband (UWB) technology has increased with the use of various civilian and military applications. In the present study, we hypothesized that low-dose UWB electromagnetic radiation (UWBR) could elicit a mitogenic effect in AML-12 mouse hepatocytes, in vitro. To test this hypothesis, we exposed AML-12 mouse hepatocytes, to UWBR in a specially constructed gigahertz transverse electromagnetic mode (GTEM) cell. Cells were exposed to UWBR for $2 \mathrm{~h}$ at a temperature of $23^{\circ} \mathrm{C}$, a pulse width of $10 \mathrm{~ns}$, a repetition rate of $1 \mathrm{kHz}$, and field strength of $5-20 \mathrm{kV} / \mathrm{m}$. UWB pulses were triggered by an external pulse generator for UWBR exposure but were not triggered for the sham exposure. We performed an MTT Assay to assess cell viability for UWBRtreated and sham-exposed hepatocytes. Data from viability studies indicated a time-related increase in hepatocytes at time intervals from 8-24 h post exposure. UWBR exerted a statistically significant $(p<0.05)$ dose-dependent response in cell viability in both serum-treated and serum free medium (SFM) -treated hepatocytes. Western blot analysis of hepatocyte lysates demonstrated that cyclin A protein was induced in hepatocytes, suggesting that increased MTT activity after UWBR exposure was due to cell proliferation. This study indicates that UWBR has a mitogenic effect on AML-12 mouse hepatocytes and implicates a possible role for UWBR in hepatocarcinoma.
\end{abstract}

Key words: Ultra-wideband radiation, nanopulse, mitogenic activity, mouse hepatocytes

\section{Introduction}

UWB technology involves the radiation, reception, and processing of wide bandwidth radio frequency emissions [1]. The global use of UWB technology has drastically increased in recent years. Exposure to UWB devices has incited public concern over potential health risks. UWBR (also known as "nanopulses") is used in radar technology and electronic warfare to illuminate objects for wideband spectral analysis [2]. UWB devices used by civilian and military organizations include: tactical handheld and network low-probability interference/detection (LPI/D) radios; LPI/D wireless intercom systems; intelligent transportation systems, electronic tags, and smart appliances; intrusion/detection radar; precision geo-location systems; and high speed data links [3]. UWB devices can transmit data over a wide spectrum of frequency bands with very low power. Moreover, low power short range microwave devices operating on various frequencies have been used in ground-penetrating radar for obtaining the images of objects buried under ground or behind surfaces; wireless communications, particularly for short-range high-speed data transmissions; home safety intrusion detection systems; and medical devices for monitoring biological systems [3].

UWBR is a form of non-thermal electromagnetic fields (EMFs), and has photon energy less than $10 \mathrm{eV}$; a level not sufficient to produce ions by ejection of orbital electrons from atoms [4]. The energy of non-thermal EMFs does not break chemical bonds directly; the effects are caused by indirect mechanisms [4]. Genetic effects of extremely low UWBR are well documented [5-7]. Exposure to extremely low UWBR has been closely linked to an increased risk of cancer and frequency of micronuclei, DNA-damage, mitogenic activity, up-regulation of heat shock proteins (hsp), and alterations in sleep patterns [8-12].

The potential risk of cancer remains a primary concern of extremely low UWBR exposure. The non- 
thermal activity of UWBR has been considered too weak to damage or mutate DNA [13, 14], however some studies indicate mutagenic or comutagenic activity $[15$, 16]. In addition, UWBR has the ability to increase proliferation in various cell types $[17,18]$. It is has been suggested that extremely low UWBR contributes to the promotional phase of cancer [18]. Extremely low UWBR has been shown to mimic the tumor-promoter agent, 12$O$-tetradecanoylphorbol-13-acetate, by inhibiting Friend erythroleukemia cell differentiation, and thereby stimulating cell proliferation [18]. In the present study, we hypothesized that low-dose UWBR could elicit a mitogenic effect in AML-12 mouse hepatocytes, in vitro.

\section{Materials and Methods}

\section{Chemicals}

Dulbecco's Modified Eagle's Medium (DMEM) was purchased from Hyclone (Lot No. ANK19799; Logan, Utah) and tissue culture supplements were purchased from American Type Culture Collection (ATCC) (Manassas, VA). Dulbecco's phosphate buffered saline (Lot No. 1163547) was obtained from Invitrogen Corporation (Grand Island, New York). Thiazolyl blue trazolium bromide (CAS 298-93-1; purity 97.5\%), $\beta$ mercaptoethanol, and dimethyl sulfoxide were purchased from Sigma-Aldrich (St. Louis, Missouri). ITS (insulintransferrin-selenium) was obtained from Cambrex BioScience Baltimore, Inc. (Baltimore, MD). Twelve percent SDS-PAGE gels were obtained from ISC BioExpress (Kaysville, UT). Cyclin A primary antibody was purchased from Calbiochem (La Jolla, CA). Alkaline phosphatase conjugated goat-anti-mouse IgG secondary antibody, and BCIP/NBT color development substrate were purchased from Promega (Madison, WI). Reagents for protein determination, gel electrophoresis, and Western analysis were obtained from Bio-Rad (Hercules, CA).

\section{Electromagnetic Field Exposure System}

The UWBR exposure facility at Louisiana Tech University, Ruston, LA, is illustrated in Figure 1. The large room was shielded with copper and steel plating and contained a GTEM cell and pulser. A D-dot probe was used to determine pulse characteristics in the GTEM cell. The output of the probe was proportional to the time derivative of the electric field. The pulser was operated from a second copper mesh, RF-shielded enclosure. A $6 \mathrm{GHz}$ bandwidth digital storage oscilloscope (Tektronix Model TDS 6400) was used to monitor pulse experiments. Cable termination panels on both rooms allowed room-to-room electrical connections.

\section{Cell Culture}

Alpha mouse liver 12 (AML 12) hepatocyte cultures were established from a mouse transgenic for human transforming growth factor $\alpha$ (ATCC CRL-2254, Manassas, VA). The cells were stored in liquid nitrogen in the laboratory until use. The contents of each vial were transferred to a $75 \mathrm{~cm}^{2}$ tissue culture flask diluted with DMEM, supplemented with $10 \%$ fetal bovine serum (FBS) and 1\% streptomycin and penicillin (hepatocyte growth medium; HGM), and incubated at $37^{\circ} \mathrm{C}$ under an atmosphere of $5 \% \mathrm{CO}_{2}$ in an incubator with humidified air to allow the cells to grow and form a monolayer in the flask. Subsequently, cells grown to 80$95 \%$ confluence were washed with phosphate buffer saline (PBS), trypsinized with $5 \mathrm{~mL}$ of $0.25 \%(\mathrm{w} / \mathrm{v})$ EDTA, diluted, counted, and seeded in two 96-well microtiter tissue culture plates $\left(5 \times 10^{5}\right.$ cells/well).

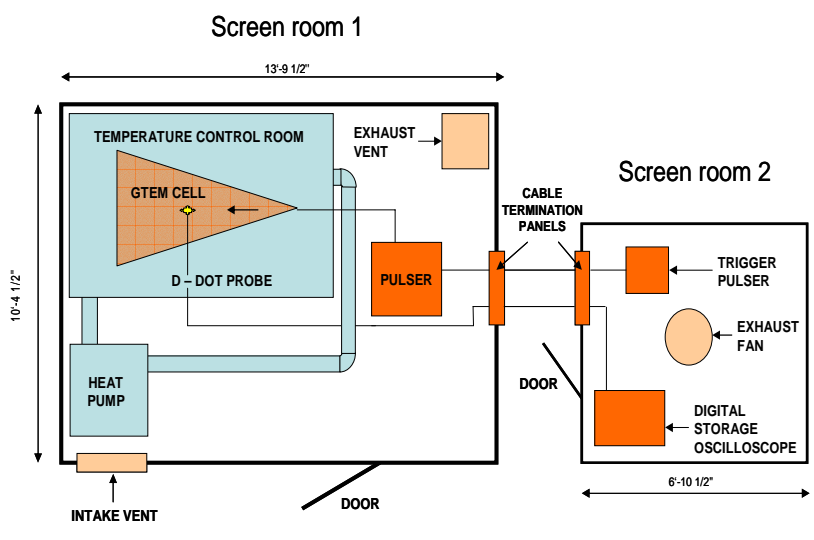

COPPER MESH SHIELDED ROOM

Figure 1: UWBR Exposure Facility at LA Tech University. Nanopulse facility was designed by Donald T. Haynie. The large room is shielded with copper and steel plating and contains a GTEM cell and pulser. A Ddot probe is used to determine pulse characteristics in the GTEM cell. The ouput of the probe is proportional to the time derivative of the electric field. The pulser is operated from a second copper mesh, RF-shielded enclosure. A $6 \mathrm{GHz}$ bandwidth digital storage oscilloscope (Tektronic Model TDS 6400) is used to monitor pulse experiments. Cable termination panels on both rooms allow room-to-room electrical connections.

\section{Exposure of Samples to UWBR}

In all experiments, cells were grown in HGM for $24 \mathrm{~h}$ prior to UWBR treatment. On the day of the experiment, medium was replaced with fresh HGM or serum-free growth medium (SFM). In some experiments, medium was supplemented with ITS at the following concentrations: .625, 1.25, 2.5, $\mu \mathrm{g}$ ITS/mL. For UWBR exposure, microtiter plates were placed in a horizontal position inside the GTEM cell. Samples were exposed to UWBR for $2 \mathrm{~h}$ at a temperature of $23^{\circ} \mathrm{C}$. The pulse width was $10 \mathrm{~ns}$, the repetition rate $1 \mathrm{kHz}$, and the applied field strength was in the range, $5-20 \mathrm{kV} / \mathrm{m}$. Pulses were triggered by an external pulse generator for exposure or not triggered for sham exposure.

\section{Cell Viability Assay}

Following a post-exposure period of 8 - to $24 \mathrm{~h}$, cell viability was evaluated using a colorimetric assay in which the reduction of a tetrazolium salt [3-(4,5dimethylthiazol-2-yl)-2,5-diphenyltetrazolium bromide] (MTT) by mitochondrial dehydrogenases of living cells was detected. In this assay, metabolically active cells 
were able to convert MTT to water-insoluble dark-blue formazan crystals. Viable cells were quantified by dissolution in $100 \%$ dimethyl sulfoxide and measured by absorbance with the wavelength set at $540 \mathrm{~nm}$, using an EL 800 Model ELISA plate reader (Bio-Tek Instruments Inc., Winooski, Vermont) [19].

\section{Sample Collection and Protein Determination}

Cells grown to $80-95 \%$ confluence were washed with PBS, trypsinized with $5 \mathrm{~mL}$ of $0.25 \%(\mathrm{w} / \mathrm{v})$ EDTA, diluted, counted, and seeded in two 96-well microtiter tissue culture plates $\left(5 \times 10^{5}\right.$ cells/well $)$. Cells were exposed to UWBR as described above. Following a post-exposure period of $24 \mathrm{~h}$, an equal volume of sample buffer $(0.2 \mathrm{~mol} / \mathrm{L}$ Tris, $\mathrm{pH} 6.8,1 \% \mathrm{SDS}, 30 \%$ glycerol, $7.5 \% \beta$-mercaptoethanol, $0.1 \%$ bromophenol blue) was added to each well. Cells were mechanically dislodged, transferred to microcentrifuge tubes, and heated at $95^{\circ} \mathrm{C}$ for $10 \mathrm{~min}$. Samples were then frozen until future use. The Bradford protein assay in a microtiter plate format was used for the determination of protein concentrations in samples. The total protein concentrations for cell lysates were quantitatively measured at $540 \mathrm{~nm}$ absorbance; using the Multiskan Ascent microplate reader (Labsystems, Beverly, MA).

\section{Western Blot and Densitometric Analyses for Cyclin A Expression}

Whole cell extracts from AML-12 mouse hepatocytes were heated at $100^{\circ} \mathrm{C}$ for $10 \mathrm{~min}$ and electrophoresed on a $12 \%$ SDS-polyacramide gel. Separated proteins were transferred onto a nitrocellulose membrane in $20 \mathrm{mM}$ Tris base, $150 \mathrm{mM}$ glycine, $20 \%$ methanol ( $\mathrm{pH} \mathrm{8.0)}$. Subsequently, the nitrocellulose membrane was blocked (10 mL of Tris-buffered saline 0.1 Tween-20 [TBST] with $5 \%$ nonfat dry milk) for $1 \mathrm{~h}$ at room temperature. Cyclin A protein was detected using cyclin A (1:200) bovine primary monoclonal antibody that was then detected with a 1:750 dilution of alkaline-conjugated goat anti-mouse $\mathrm{IgG}$, secondary antibody. BCIP/NBT color substrate was incorporated to develop protein bands. Immunoblot protein bands were assessed for abundance by TotalLab computer software (Nonlinear USA Inc. Durham, NC)

\section{Statistical Analysis}

Results are given as the mean \pm SDs for the indicated number of independently performed experiments. Differences between the mean values were evaluated by Student's $t$ test.

\section{Results}

The effects of UWBR on the viability of AML-12 mouse hepatocytes are shown in Figure 2. In this experiment, we exposed hepatocytes to low-dose UWBR for $2 \mathrm{~h}$, as indicated in the methodology section. Results from this experiment demonstrated a statistically significant $(p<0.05)$ time-related increase in cell viability within the post-exposure periods of $8-24 \mathrm{~h}$. The maximum increase in cell viability was $38 \%$ at the $24 \mathrm{~h}$ post-exposure period.

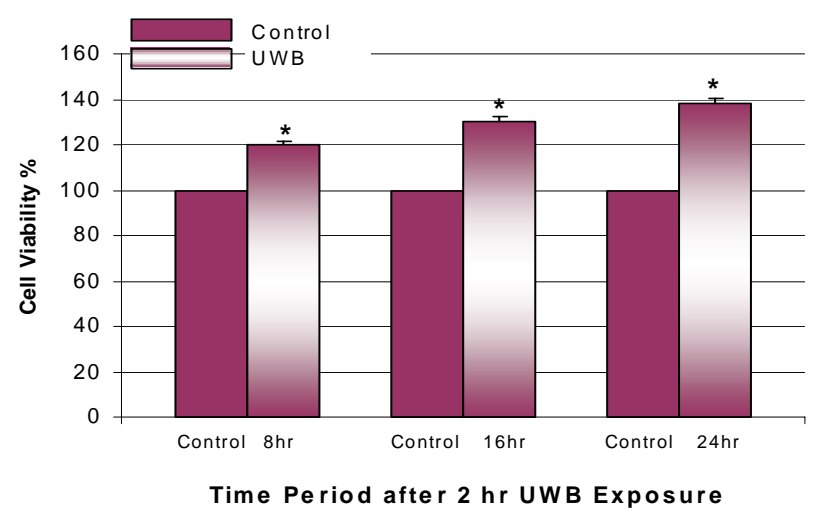

Figure 2: Mitogenic effect of UWBR on HGM-treated AML-12 mouse hepatocytes. HGM-treated AML-12 mouse hepatocytes were exposed to UWB pulses for $2 \mathrm{~h}$ at a temp of $23^{\circ} \mathrm{C}$, pulse width of $10 \mathrm{~ns}$, repetition rate of $1 \mathrm{kHz}$, and applied field strength of $5-20 \mathrm{kV} / \mathrm{m}$. Cell viability was assessed following a post-exposure incubation period of 8-24 h. In this assay, viable cells converted MTT to a water-insoluble formazan dye, as indicated in the methodology section. Bars are means \pm SDs, $n=3$. *Significantly different from control, $p \leq 0.05$.

We also investigated whether UWBR could cause a similar response under the same conditions for SFMtreated hepatocytes for a post-exposure period of $24 \mathrm{~h}$. The comparison of SFM- and HGM-treated hepatocytes exposed to low-dose UWBR is shown in Figure 3. Upon the post-exposure period of $24 \mathrm{~h}$, UWBR had a smaller but significant $(p<0.05)$ stimulatory effect on cell viability in SFM-treated cells. These results suggest that the low field strength $(5-20 \mathrm{kV} / \mathrm{m})$ of UWBR elicits a greater proliferative effect in HGM-treated AML-12 mouse hepatocytes.

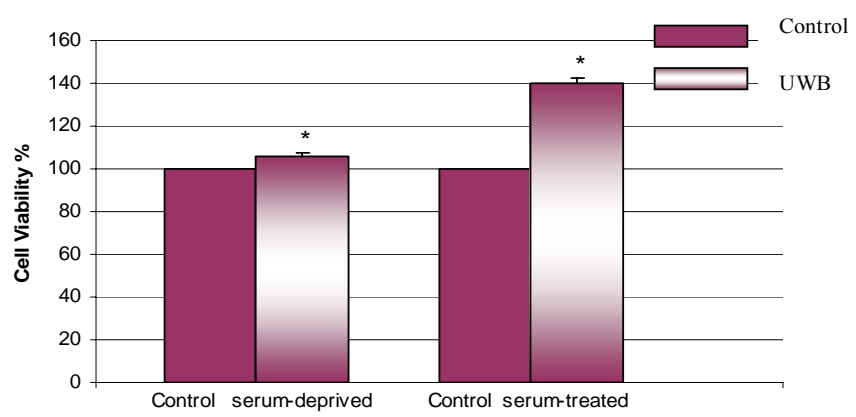

24 hr Time Period after UWB Exposure

Figure 3: Effect of UWBR on HGM and SFM AML-12 mouse hepatocytes. HGM and SFM AML-12 mouse hepatocytes were exposed to UWB pulses for $2 \mathrm{~h}$ at a temp of $23^{\circ} \mathrm{C}$, pulse width of $10 \mathrm{~ns}$, repetition rate of 1 $\mathrm{kHz}$, and applied field strength of $5-20 \mathrm{kV} / \mathrm{m}$. Cell viability was assessed following a post-exposure incubation period of $24 \mathrm{~h}$. In this assay, viable cells converted MTT to a water-insoluble formazan dye, as indicated in the methodology section. Bars are means \pm SDs, $\mathrm{n}=3$. *Significantly different from control, $p \leq$ 0.05 . 
Next, we examined the effect of UWBR on AML-12 mouse hepatocytes maintained in HGM- and SFM containing ITS, Figure 4. A dose-dependent response was demonstrated in HGM-treated hepatocytes with ITS; showing a statistically significant $(p<0.05)$ increase in cell viability within the dose range of .625-2.5 $\mu \mathrm{g}$ ITS $/ \mathrm{mL}$. For example, cell viability percentages of 119 $\pm .16 \%, 127 \pm .18 \%$, and $147 \pm .22 \%$, were recorded for $.625,1.25$, and $2.5, \mu \mathrm{g} \mathrm{ITS} / \mathrm{mL}$, respectively. The greatest observed effect was a 1.5 -fold increase in proliferation at $2.5 \mu \mathrm{g} I T S / \mathrm{mL}$. With regard to SFMtreated hepatocytes containing ITS, a dose-dependent effect was also demonstrated within the dose range of $.625-2.5 \mu \mathrm{g} \mathrm{ITS} / \mathrm{mL}$. Statistically significant $(p<0.05)$ cell viability percentages were recorded as $108 \pm .23 \%$, $103 \pm .17 \%$, and $105 \pm .19 \%$. Under SFM conditions, the highest increase in cell viability was observed at .625 $\mu \mathrm{g}$ ITS $/ \mathrm{mL}$; representing 1-fold increase.

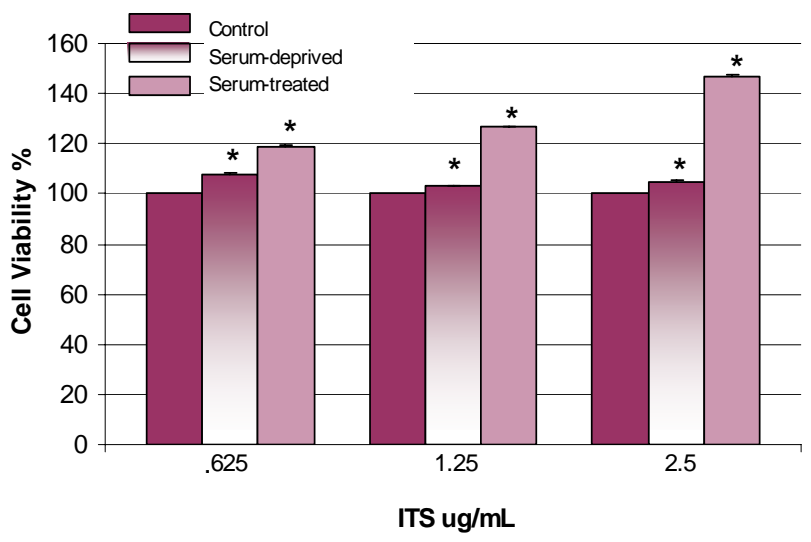

Figure 4: Effect of UWBR on HGM- and SFM-treated AML-12 mouse hepatocytes in the presence of ITS. HGM- and SFM-treated AML-12 mouse hepatocytes in the presence of ITS were exposed to UWB pulses for $2 \mathrm{~h}$ at a temp of $23^{\circ} \mathrm{C}$, pulse width of $10 \mathrm{~ns}$, repetition rate of $1 \mathrm{kHz}$, and applied field strength of $5-20 \mathrm{kV} / \mathrm{m}$. Cell viability was assessed following a post-exposure incubation period of $24 \mathrm{~h}$. Data in this figure indicate a biphasic relationship with regard to cell viability in serum-treated cells. The mean levels of cell viability were: $119 \pm .16 \%, 127 \pm .18 \%$, and $147 \pm .22 \%$ in .625 , 1.25 and $2 . \overline{5} \mu \mathrm{g} \mathrm{ITS} / \mathrm{mL}$, respectively. Bars are means \pm SDs, $\mathrm{n}=2$ with 32 replications per concentration. $*$ Significantly different from control, $p \leq 0.05$.

To determine whether the increase in MTT activity resulted from an increase in proliferation, we tested the ability of UWBR to stimulate the induction of the cyclin A protein in AML-12 mouse hepatocytes. A qualitative identification of cyclin A protein was made by Western blot analysis and quantitative assessment by densitometric analysis. Densitometric analysis of cyclin A expression in control and UWBR-treated mouse hepatocytes is shown in Figure 5. The mitogenic activity of UWBR was evidenced by the induction of the $60-\mathrm{kDa}$ cyclin A protein in UWBR-treated mouse hepatocytes. The overexpression of the cyclin A protein in hepatocytes constitutes an indication of the mitogenic activity of UWBR.

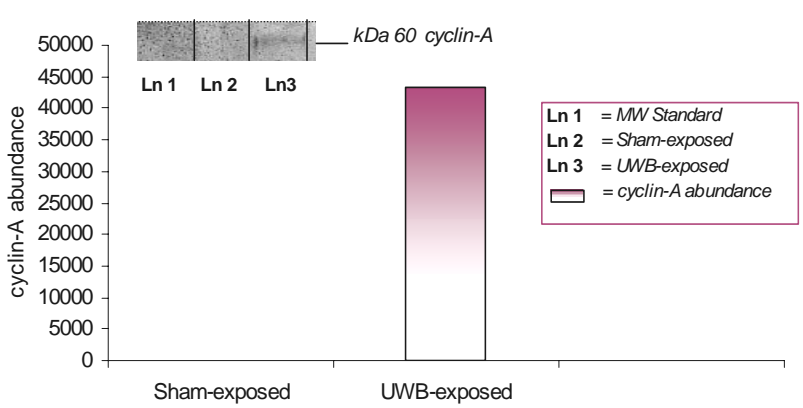

Figure 5: Western blot for cyclin- $A$ expression and densitometric analysis in UWBR-treated AML-12 mouse hepatocytes. AML-12 mouse hepatocytes were exposed to UWB pulses for $2 \mathrm{~h}$ at a temp of $23^{\circ} \mathrm{C}$, pulse width of $10 \mathrm{~ns}$, repetition rate of $1 \mathrm{kHz}$, and applied field strength of $5-20 \mathrm{kV} / \mathrm{m}$. Cyclin A protein identification was assessed following a post-exposure incubation period of $24 \mathrm{~h}$. Inset shows representative Western blot analysis. Densitometric analysis shows an increase in cyclin A abundance at 43,221 .

\section{Discussion}

Recent investigations from our laboratory have demonstrated that PCP, a tumor-promoter agent, has the ability to induce cell proliferation in AML-12 mouse hepatocytes [20]. We chose the AML-12 mouse hepatocyte cell line to study the mitogenic effect of UWBR, in vitro, because hepatocarcinoma is the primary form of liver cancer that arises from hepatocytes. Data presented in this study show that UWBR induced an increase in cell viability of AML-12 mouse hepatocytes, measured by MTT incorporation (Figure 2). It has been suggested that extremely low UWBR plays a role in the carcinogenic process by eliciting tumor-promoting effects, and therefore, is likely to be involved in the promotional phase of cancer [18]. Moreover, it has been shown that the tumor-promoting effects of extremely low EMFs inhibited differentiation and stimulated proliferation of Friend erythroleukemia cells [18]. Our results are similar to those of Chen et al. [18], who demonstrated that extremely low EMFs stimulated cell proliferation $50 \%$ above the sham-treated Friend erythroleukemia cells.

In the present study, we used the GTEM cell for exposing our cells to UWBR. The uniformity of GTEM field exposure is critical to quantifying the biological response versus the electromagnetic dose [21]. Moreover, conducting medium, such as culture medium in vitro, in combination with GTEM field exposure are determinant factors for dose-dependent effects of EMF on biological cells [21]. Various studies have shown that EMFs have a proliferative effect on cells in culture medium containing growth additives [22-24]. In our experiments, we used HGM-and SFM conditions to compare the effects of UWBR on AML-12 mouse hepatocytes. We observed a higher level of MTT activity in HGM-grown cells compared to those grown in SFM, but both showed increased MTT activity compared to control (Figure 3). Typically, serum-free conditions cause cells to withdraw from the cell cycle 
and/or differentiate. A previous investigation exposed human chrondocytes to low-frequency pulsed EMFs in medium supplemented with $10 \%$ or $0.5 \%$ fetal calf serum and in serum-free medium [24]. As a result, ${ }^{3} \mathrm{H}-$ thymidine incorporation showed an increase of cell proliferation in cultures exposed to low-frequency pulsed EMFs when serum was present in the culture medium, whereas no effect was observed in serum-free conditions [24]. The same study concluded that the proliferative response of chondrocytes to the low-frequency pulsed EMF exposure was dependent on the amount of serum in the culture medium [24]. It was further suggested that increased DNA synthesis of chondrocytes was dependent on the amount of fetal calf serum which is similar to the basic mechanism of low-frequency pulsed EMF stimulation of fracture healing [24]. Data obtained from our experiments demonstrated a similar pattern in SFMtreated hepatocytes exposed to UWBR; indicating that UWBR has very little effect on hepatocytes under serum-free conditions. Our results show that the greatest mitogenic response of mouse hepatocytes to UWBR exposure is dependent on the presence of FBS in the culture medium.

We have shown that the addition of ITS (insulin, transferrin, and selenium), a mitogen, causes a dosedependent response in HGM- and SFM-treated cells. Cytokinetic analysis using fluorescence flow cytometry and microscopic techniques indicated that selenium treatment increased the duration of $\mathrm{G} 1, \mathrm{~S}$, and $\mathrm{G} 2$ phases of the cell cycle [25]. It has been suggested that the presence of growth factors and mitogens in culture medium is necessary to obtain an induction of cell proliferation after low-frequency pulsed EMF exposure; indicating that the interaction between cell membrane receptors and mitogens is one of the molecular events affected by extremely low EMFs [24, 26]. Cossarizza and colleagues [26] demonstrated that low-frequency pulsed EMF exposure induced an increase of cell proliferation and IL-2 receptor expression only in phytohemagglutinin (PHA) -stimulated lymphocytes, whereas no effect was observed when PHA was not added to the culture medium.

Cell proliferation and progression through the cell cycle are regulated by the sequential events of various cyclin-dependent kinases (cdks) [27, 28]. Cyclin A is required for cell cycle $\mathrm{S}$ phase entry, and its overexpression has been strongly linked to tumorigenesis [29]. Moreover, cyclin A is considered to be a ratelimiting component required for both the initiation of DNA synthesis and entry into mitosis [30]. In the present study, we have established that UWBR causes the upregulation of cyclin A (Figure 5). It has been suggested that cyclin $\mathrm{A}$ is a direct transcriptional target of JunB, thus, driving cell proliferation [30].

Biological membranes have an appreciable electrical capacity to store and separate charges. Exposure to EMFs induces currents into tissues, and therefore, bioeffects that are dependent on frequency, wave shape, and intensity. Cellular stress caused by exposure to EMFs may trigger a change in metabolic activities, cell cycle reaction rates, cell morphology, electrical charges across the plasma membrane, and gene expression in the nucleus [31-34]. In addition, EMFs can have a regulatory affect on free radical- and enzymatic reactions in biological systems $[35,36]$. One study found that treatment of rats before exposure to EMFs with free radical scavengers, melatonin and N-tert-butyl- $\alpha$ phenylnitrone, blocked the effects of EMF on DNA single- and double-stranded breaks in their brain cells [37]; thus suggesting that EMF enhances free radical activity in cells, which in turn lead to DNA-damage. Another investigation exposed a mast cell line, RBL$2 \mathrm{H} 3$, to an EMF of $835 \mathrm{MHz}$ and showed an increased rate of DNA synthesis and cell replication [34]. The same study associated alterations in actin distribution, cell morphology, and calcium ionophore to EMF exposure [34]. A recent investigation demonstrated that in vitro exposure of human peripheral blood lymphocytes to continuous $830 \mathrm{MHz}$ EMFs caused an increase in chromosomes (aneuploidy), a phenomenon known to increase the risk for cancer [38]. Results from the same study suggest that the genotoxic effect of the EMF is elicited via a non-thermal pathway [38]. EMF ability to stimulate cell proliferation has been demonstrated in human astrocytoma cells exposed to EMFs of $60-\mathrm{Hz}$ [17]. It has been suggested that cells with high rates of iron intake, especially proliferating cells, and cells with high metabolic rates would be more sensitive to the effects of EMFs [4]. Well-documented studies show that extremely low EMFs, such as UWBR, can alter the transcription and translation of various genes [8, 39].

Various studies suggest that the interaction site for extremely low UWBR is the plasma membrane, since exposure can alter $\mathrm{Ca}^{2+}$ influx [40, 41]. Increases in intracellular ( ${ }_{\mathrm{I}} \mathrm{Ca}^{2+}$ can be mediated by $\mathrm{Ca}^{2+}$ influx across the plasma membrane and/or by $\mathrm{Ca}^{2+}$ release from internal compartments [41]. ${ }_{\mathrm{I}} \mathrm{Ca}^{2+}$ plays an intimate role in regulating cell migration, differentiation, proliferation, and signal transduction pathways. Hepatocytes are target cells for biotransformation; however, they lack voltagegated $\mathrm{Ca}^{2+}$ channels in their membrane, and maintain $\mathrm{Ca}^{2+}$ at greater levels outside the cell with the exception of ${ }_{\mathrm{I}} \mathrm{Ca}^{2+}$ compartments. Hepatocytes used calcium pumps to direct the flow of calcium ions through the plasma membrane. This event causes $\mathrm{Ca}^{2+}$ ions to move from the extracellular fluid, and from intracellular storage sites, into the cytoplasm. In a previous study that used a mammalian hepatoma cell line (supplemented with $10 \%$ fetal calf serum), the application of a 1 or $10 \mathrm{~Hz}$ electric field to human hepatoma (Hep3B) cells induced a fourfold increase in ${ }_{\mathrm{I}} \mathrm{Ca}^{2+}[40]$. The consequence of increased cytosolic $\mathrm{Ca}^{2+}$ is activation of a class of enzymes known as protein kinases, positive regulators of cell cycle progression. Some members of the protein kinase family play a role in the control of cell proliferation and survival. In the present study, a possible explanation for increased cell viability in HGM-treated hepatocytes is that UWBR activates $\mathrm{Ca}^{2+}$ pumps; thereby releasing ${ }_{\mathrm{I}} \mathrm{Ca}^{2+}$ and increasing cytosolic $\mathrm{Ca}^{2+}$.

\section{Conclusions}

It can therefore be concluded from the findings of this research that: 1) Low-dose UWBR caused a 
mitogenic response in AML-12 mouse hepatocytes. 2) During the post-exposure period of 8-24 h, a dosedependent increase in cell viability was demonstrated in HGM-treated hepatocytes. 3) In the presence of HGMand SFM-treated hepatocytes coupled with ITS, a dosedependent response was also demonstrated with regard to cell viability. 4) Low-dose UWBR caused 1.5-fold $(p<0.05)$ increase in cell viability at $2.5 \mu \mathrm{g}$ ITS $/ \mathrm{mL}$ in HGM-treated AML-12 mouse hepatocytes. 5) Cell proliferation activity in AML-12 mouse was confirmed by UWBR ability to up-regulate the $60-\mathrm{kDa}$ cyclin $\mathrm{A}$ protein.

Acknowledgments: This research was financially supported in part by a subcontract from LA-Tech University (Ruston, LA) under the Air Force Office of Scientific Research (Contract No. F49620-02-1-0136), and in part by a grant through the Title III Research Excellence Fund at Grambling State University, Grambling, LA. We thank Dr. Matthew Ware, Chairman of Physics Department, Grambling State University (Grambling, LA) for his valuable support and advice on this research.

\section{References}

1 Ross, G. F.: A time domain criterion for the design of wideband radiating elements. IEEE Transactions on Antennas and Propagation. 1968, 16(3), 355.

2 Lu, S. T.; Mathur, S. P.; Akyel, Y.; Lee, J.C. Ultrawideband electromagnetic pulses induced hypotension in rats. Physio Behav., 1999, 65(4-5), 753-761.

3 Seamen, R. L.; Parker, J. E.; Kiel, J. L.; Mathur, S. P.; Grubbs; Prol, H. K.: Ultra-wideband pulses increase nitric oxide production by RAW 264.7 macrophages incubated in nitrate. Bioelectromagnetics, 2002, 23, 83-87.

4 Lai, H.: Genetic effects of nonionizing electromagnetic fields. Paper presented at the "International Workshop on Biological Effects of Ionizing Radiation, Electromagnetic Fields and Chemical Toxic Agents" in Sinaia, Romania, October 2-6, 2001.

5 Maes, A.; Verschaeve, L.; Arroyo, A.; De Wagter, C.; Vercruyssen, L. In vitro cytogenetic effects of 2450 $\mathrm{MHz}$ waves on human peripheral blood lymphocytes. Bioelectromagnetics, 1993, 14, 495-501.

6 Simko, M.; Kriehuber, R.; Weiss, D. G.; Luben R. A.: Effects of $50 \mathrm{~Hz}$ EMF exposure on micronucleus formation and apoptosis in transformed and nontransformed human cell lines. Bioelectromagnetics, 1998, 19, 85-91.

7 Zotti-Martelli, L.; Peccatori, M.; Scarpato, R.; Migliore L.: Induction of micronuclei in human lymphocytes exposed in vitro to microwave radiation. Mutat Res., 2000, 472, 51-58.

8 de Pomerai, D.; Daniels C.; David H.; Allan J.; Duce I.; Mutwakil M.; Thomas D.; Sewell P.; Tattersall, J.; Jones, D. Non-thermal heat-shock response to microwaves. Nature, 2000, 405, 417-418.

9 Leszczynski, D.; Joenvaara, S.; Reivinen, J.; Kuokka, R.: Non-thermal activation of the hsp27/p38MAPK stress pathway by mobile phone radiation in human endothelial cells: molecular mechanism for cancer- and blood-brain barrierrelated effects. Differentiation, 2002, 70, 120-129.

10 Mann, K.; Röschke, J.: Effects of pulsed highfrequency electromagnetic fields on human sleep. Neuropsychobiology, 1996, 33, 41-47.

11 Lai H.; Singh, N. P.: Acute low-intensity microwave exposure increases DNA single-strand breaks in rat brain cells. Bioelectromagnetics, 1995, 16, 207-210.

12 Garaj-Vrhovac, V.: Micronucleus assay and lymphocyte mitotic activity in risk assessment of occupational exposure to microwave radiation. Chemosphere, 1999, 39(13), 2301-2312.

13 McCann, J.; Dietrich, F.; Rafferty, C.; Martin, A. O.: A critical review of the genotoxic potential of electric and magnetic fields. Mutat Res., 1993, 297, 61-95.

14 McCann, J.; Dietrich, F.; Rafferty, C.: The genotoxic potential of electric and magnetic fields: an update. Mutat Res., 1998, 411, 45-86.

15 Miyakoshi, J.; Koji, Y.; Wakasa, T.; Takebe, H. Long-term exposure to a magnetic field $(5 \mathrm{mT}$ at 60 $\mathrm{Hz}$ ) increases X-ray-induced mutations. J Radiat Res (Tokyo), 1999, 40, 13-21.

16 Walleczek, J.; Shiu, E. C.; Hahn, G. M.: Increase in radiation-induced HPRT gene mutation frequency after nonthermal exposure to nonionizing $60 \mathrm{~Hz}$ electromagnetic fields. Radiat Res., 1999, 151, 489-497.

17 Wei, M.; Guizzetti, M.; Yost, M.; Costa, L. G.: Exposure to $60-\mathrm{Hz}$ magnetic fields and proliferation of human astrocytoma cells in vitro. Toxicol Appl Pharmacol., 2000, 162(3),166-76.

18 Chen, G.; Upham, B.L.; Sun, W.; Chang, C. C.; Rothwell, E.J.; Chen, K.M.; Yamasaki, H; Trosko, J. E.: Effect of electromagnetic field exposure on chemically induced differentiation of Friend erythroleukemia cells. Environmental Health Perspectives, 2000, 108(10), 967-972.

19 Mosmann,T.: Rapid colorimetric assay for cellular growth and survival: Applications to proliferation and cytotoxicity assays. J. Immunol. Methods, 1983, 65, 55-63.

20 Dorsey, W. C.; Tchounwou, P. B.; Sutton, D.: Mitogenic and cytotoxic effects of pentachlorophenol to AML 12 Mouse Hepatocytes. Int. J. Environ. Res. Public Health, 2004, 1(2), 100-105.

21 Popovic, M.; Hagness, S. C.: Finite-difference timedomain analysis of a complete transverse electromagnetic cell loaded with liquid biological media in culture dishes. IEEE Transactions on Biomedical Engineering, 1998, 45(8), 1067-1076.

22 Gilroy, D. W.; Saunders, M. A.; Sansores-Garcia, L.; Matijevic-Aleksic, N.; Wu, K. K.: Cell cycledependent expression of cyclooxygenase-2 in human fibroblasts. FASEB J., 2001, 15, 288-290.

23 Walleczek, J.; Liburdy, R. P.: Nonthermal $60 \mathrm{~Hz}$ sinusoidal magnetic-field exposure enhances ${ }^{45} \mathrm{Ca}^{2+}$ uptake in rat thymocytes: dependence on mitogen activation. FEBS Lett., 1990, 271, 157-160.

24 Pezetti, F.; De Mattei, M.; Caruso, A.; Cadossi, R.; Zucchini, P.; Carinci, F.; Traina, G. C.; Sollazzo, V.: Effects of pulsed electromagnetic fields on human chondrocytes: an in vitro study. Calcif Tissue Int. 1999, 65, 396-401. 
25 LeBoeuf, R. A.; Laishes, B. A.; and Hoeskstra, W. G.: Effects of selenium on cell proliferation in rat liver and mammalian cells as indicated by cytokinetic and biochemical analysis. Cancer Research, 1985, 45(11), 5496-5504.

26 Cossarizza, A.; Monti, D.; Bersani, F.; Paganelli, R.; Montagnani, G.; Cadossi, R.; Cantini, M.; Franceschi, C.: Extremely low frequency pulsed electromagnetic fields increase in interleukin-2 (IL2) utilization and IL-2 receptor expression in mitogen-stimulated human lymphocytes from old subjects. FEBS Lett., 1989, 248, 141-144.

27 Chellappan, S. P.; Giordano, A.; Fisher, P. B.: Role of cyclin-dependent kinases and their inhibitors in cellular differentiation and development. Curr Top Microbiol Immunol., 1998, 227, 57-103.

28 Pavletich, N. P.: Mechanisms of cyclin-dependent kinase regulation: structures of Cdks, their cyclin activators, and Cip and INK4 inhibitors. J Mol Biol. 1999, 287, 821-828.

29 Shen, W. H.; Yin, Y.; Broussard, S. R.; McCusker, R. H.; Freund, G. G.; Dantzer, R., Kelly, K. W.: Tumor necrosis factor alpha inhibits cyclin A expression and retinoblastoma hyperphosphorylation triggered by insulin-like growth factor-I induction of new E2F-1 synthesis. J. Biol. Chem., 2004, 279(9), 7438-7446.

30 Pagano, M.; Pepperkok, R.;Verde, F.; Ansorge, W.; Draetta, G.: Cyclin A is required at two points in the human cell cycle. The EMBO J., 1992, 11, 961-971.

31 Velizaro, S.; Raskmark, P.; Kwee, S.: The effects of radiofrequency fields on cell proliferation are nonthermal. Bioelectrochem Bioenerg, 1999, 48(1), 177-180.

32 Fesenko, E. E.; Geletyuk, V. I.; Kazachenko, V. N.; Chemeris, N. K.: Preliminary microwave irradiation of water solutions changes their channel-modifying activity. FEBS Lett., 1995, 366(1), 49-52.

33 Goswami, P. C.; Albee, L. D.; Parsian, A. J.; Baty, J. D.; Moros, E. G.; Pickard, W. F.; Roti-Roti, J. L.;
Hunt, C. R.: Expression of proto-oncogene and activities of multiple transcription factors in RF exposed cells, using C3H10T1/2 mouse embryo fibroblast cells exposed to $835.62 \mathrm{NS} 847.74 \mathrm{MHz}$ cellphone radiations. Radiat Res., 1999, 151(3), 300-309.

34 Donnelian, M.; McKenzie, D. R.; French, P. W.: Effects of exposure to electromagnetic radiation at $385 \mathrm{MHz}$ pm growth, morphology and secretory characteristics of a mast cell analogue, RBL-2H3. Cell Biol Int., 1997, 21, 427-439.

35 Brocklehurst, B.; McLauchlan, K. A.: Free radical mechanism for the effects of environmental electromagnetic fields on biological systems. Int. H. Radiat Biol., 1996, 69, 3-24.

36 Mohtat, N.; Cozens, F. L.; Hancock-Chen T.; Scaiano, J. C.; McLean, J.; Kim, J.: Magnetic field effects on the behavior of radicals in protein and DNA environments. Photochem Photobiol. 1998, 67, 111-118.

37 Lai, H.; Singh, N. P.: Melatonin and N-tert-butyl- $\alpha-$ phenylnitrone blocked $60-\mathrm{Hz}$ magnetic fieldinduced DNA single and double strand breaks in rat brain cells. J Pineal Res. 1997, 22, 152-162.

38 Mashevich, M.; Folkman, D.; Kesar, A.; Barbul, A.; Korenstein, R.; Jerby, E., Avivi, L.: Exposure of human peripheral blood lymphocytes to electromagnetic fields associated with cellular phones leads to chromosomal instability. Bioelectromagnetics, 2003, 24(2), 82-90.

39 Phillips, J. L.; Haggren, W.; Thomas, W.J.; Ishida, T. T.; Adey, W. R.: Magnetic field-induced changes in specific gene transcription. Biochim Biophys Acta. 1992, 1132, 140-144.

40 Fanelli, C.; Coppola, S.; Barone, R.; Colussi, C.; Gualandi, G.; Volpe, P.; Ghibelli, L.: Magnetic fields increase cell survival by inhibiting apoptosis via modulation of $\mathrm{Ca}^{2+}$ influx. FASEB J., 1999, 13, 95-102.

41 Cho, M. R.; Thatte, H. S.; Silvia, M. T.; Golan, D. E. Transmembrane calcium influx induced by ac electric fields. FASEB J., 1999, 13, 677-683. 